\title{
Evaluation of Adding Potassium lodide and Thyroxin to Sea bream (Sparus aurata) Fingerlings Diets Containing Fenugreek as a Growth Promoter
}

\author{
Ashraf El-Dakar ${ }^{1}$, Shymaa Shalaby ${ }^{1}$, Bahig Nemetalla ${ }^{2}$, Norhan Saleh ${ }^{3}$, Eman Sakr ${ }^{3}$, \\ Mohamed Toutou ${ }^{3}$ \\ ${ }^{1}$ Quaculture Department, Faculty of Fish Resources Suez University, Suez \\ ${ }^{2}$ Hysiology Department, Faculty of Veterinary Medicine Alexandria University, Edfina \\ ${ }^{3}$ Ish Nutrition Lab. National Institute of Oceanography and Fisheries, Alexandria, Egypt
}

\section{Email address:}

adakar90@yahoo.com (A. El-Dakar), shymaashalaby@yahoo.com (S. Shalaby),dr_riad_bahig@yahoo.com (B. Nemetalla), norraafat@yohoo.com (N.Saleh), emano@hotmail.com (E. Sakr),mtoutou50@yahoo.com (M. Toutou)

\section{To cite this article:}

Ashraf El-Dakar, Shymaa Shalaby, Bahig Nemetalla, Norhan Saleh, Eman Sakr, Mohamed Toutou. Evaluation of Adding Potassium Iodide and Thyroxin to Sea bream (Sparus aurata) Fingerlings Diets Containing Fenugreek as a Growth Promoter. American Journal of Life Sciences. Special issue: New Horizons in Basic and Applied Zoological Research. Vol. 3, No. 6-1, 2015, pp. 53-61.

doi: $10.11648 /$ j.ajls.s.2015030601.18

\begin{abstract}
This study was conducted to investigate the effect of addition of potassium iodide and thyroxin to sea bream fingerlings diets containing fenugreek as growth promoter on growth performance, feed utilization, body composition, biometric measurements indices, some serum constituents and histological characteristics of sea bream intestine. The 1st group was considered as a control which fed on the basal diet (C) for 84 days. The experiment was designed to determine the effects of using $2 \%$ fenugreek $/ \mathrm{kg}$ diet (F), $2 \%$ fenugreek $+0.05 \mathrm{mg}$ thyroxin $/ \mathrm{kg}$ diet (FT4), and $2 \%$ fenugreek $+0.1 \mathrm{~g}$ potassium iodide $/ \mathrm{kg}$ diet (Fi). The results of the present study showed that the best growth performance and feed utilization values were recorded in fish fed diets supplemented with F. The lowest growth performance and feed utilization values were recorded in fish fed diet supplemented with iodine when compared with corresponding values in case of C group. Histological analysis showed satisfactory values in F and FT4 groups compared to the control.
\end{abstract}

Keywords: Sparus aurata, fenugreek, Iodine, Thyroxin, Growth, Feed Utilization, Body Composition, Serum Constituents, Middle Intestine Morphology

\section{Introduction}

In recent years, the concept of "functional foods" has developed in human and animal nutrition. A "functional nutrient" can be further defined as a dietary ingredient that exerts possible positive effects on health in addition to its direct role as a nutrient [1]. Medicinal and aromatic plants include a huge number of spices and herbs that have been used as human drugs before pharmacological compound are discovered. Spices are a will know appetizers and add flavor to food. Some of these spices have antioxidant properties, antimicrobial, antifungs and antibiotic activity [2]. Medicinal and aromatic plants may be used as feed additives. They are important materials that can improve feed efficiency and animal performance. Fenugreek was found to be rich in protein, fat, total carbohydrates and minerals such as calcium, phosphorous, iron, zinc and magnesium [3]. [4] Revealed that protein concentrate of fenugreek seeds are rich in lysine, being $6.51 \mathrm{~g} / 100 \mathrm{~g}$ crude protein (CP), whereas they are deficient in methionine, cystine and tryptophane, being 0.71 , 1.09 and $1.03 \mathrm{~g} / 100 \mathrm{~g} \mathrm{CP}$, respectively. Free amino acids, such as 4 - hydroxyisoleucine $(0.09 \%)$; arginine, histidine and lysine; saponin (0.6-1.7\%); glycosides yielding steroidal sapogenins on hydrolysis (diosgenin, yamogenin, tigogenin, neotigogenin); cholesterol and sitosterol; vitamins A, B1, C and nicotinic acid; coumarin compounds and $0.015 \%$ volatile oils.

Iodine is related to thyroid hormones which regulate the 
level of metabolic activity in fish. These hormones have wide influence on cellular oxidation, neuromuscular control, circulatory dynamics, nutrient metabolism and growth. Triiodothyronine (T3) is the major hormone of the thyroid gland and is supposed to be the active precursor for thyroxin (T4). Fish differ from mammals in iodine utilization and in thextrathyroidal metabolism of T3 and T4 [5]. The present work was conducted to investigate the effects of using Iodine and thyroxin to sea bream (Sparus aurata) fingerlings diets containing fenugreek as growth promoters, feed conversion, nutrient retention efficiencies, body composition, biometric measurements indices, some serum and histological analysis of intestine

\section{Materials and Methods}

\subsection{Experimental Fish Facilities and Feeding Regime}

Gilthead seabream fingerlings were obtained from EL-Wfa Marine Fish Hatchery (Ismailia governorate) and transferred to Fish Nutrition Lab. NIOF, Anfoushy- Alexandria. Fish were acclimatized to the laboratory conditions for 20 days. Healthy fish were randomly distributed in 12 glass aquaria (100 L each) at a density of 16 fish per aquarium with an average weight $1.9 \pm 0.2 \mathrm{~g} /$ fish as triplicate groups per treatment. Continuously aerated sea water was used within the flow through system. The aquaria were daily cleaned and excreta were siphoned. Light was about 12:12 hour light: dark cycle throughout the day. Water quality parameters were monitored on a weekly basis throughout the experimental period using standard [6]. Water temperature $\left(20^{\circ} \mathrm{C} \pm 2\right)$,

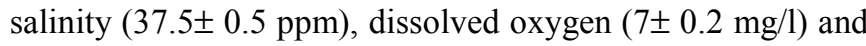
$\mathrm{pH}(7.9 \pm 0.1)$. Feeding trials fish were fed the test diets until visual apparent satiation, 7 days a week for 84 days. Fish in each aquarium were counted and weighed (collectively) biweekly throughout the feeding trials. The total amount of feed consumed by the fish in each aquarium, during the study period, was determined and feed consumed for each individual fish was calculated accordingly.

\subsection{Experimental Diets}

Isonitrogenous ( $\sim 45 \%$ crude protein), isocaloric $(\sim 477$ $\mathrm{Kcal} / 100 \mathrm{~g}$ gross energy, GE) test diets were prepared by using the additives quantity of experimental diets (Table1). The ingredients were blended with additional water to make a paste of each diet. The pastes were passed through a grinder and pelleted (the pellets into the appropriate size suitable for the experimental fish size) in a paste extruder. The diets dried into an oven thermostatically regulated at $60^{\circ} \mathrm{C}$ for 36 hours and stored in plastic bags at $-20{ }^{\circ} \mathrm{C}$ for further use.

\subsection{Data Collection and Samples Analyses}

At the end of experiments, the fish of each treatment were weighed collectively and average final weight (g/fish) was calculated. Some biological data on: Total lengths $(\mathrm{cm})$, total and gutted body weights (g) were calculated.

\subsection{Blood Sample: Hematology}

The blood samples from 6 fish of the different groups were collected by suction from the caudal peduncle. Whole blood samples were collected in small plastic vials.

\subsection{Serum Constituents}

Blood samples were collected and transferred to centrifuge tubes and allowed to clot at room temperature. Serum was then separated by centrifugation at 3000 (rpm) for 20 minutes The serum was stored at $-20^{\circ} \mathrm{C}$ until further analysis. Serum total protein $(\mathrm{g} / \mathrm{dl})$ was determined calorimetrically using kits supplied by Elnasr Pharmaceutical Chemicals Co. (Egypt). Serum total lipid (g/dl); Serum cholesterol (mg/dl); lipase and amylase activities were determined calorimetrically using commercial kit's DIAMOND ${ }^{\mathrm{TM}}$ DIAGNOSTIC Co. (Egypt). Serum thyroxin $(\mathrm{T} 4)(\mu \mathrm{g} / \mathrm{dl})$ concentrations were determined by F.Diagnostika mbH, Germany. Wellcozyme model V. $1.1 \mathrm{Rs}-232 \mathrm{C}$ by EFLAB and BIORAD model 1575 Immuno wash ADIL Institute.

Table (1). The composition and Chemical analyses (\% on dry matter basis) of the experimental diets.

\begin{tabular}{|c|c|c|c|c|}
\hline \multirow{2}{*}{ Ingredients composition } & \multicolumn{4}{|c|}{ Composition (\%) experimental diets. } \\
\hline & Control & Fenugreek (F) & Fenugreek + T4 (FT4) & Fenugreek + I (Fi) \\
\hline Fish meal (68\%) & 50 & 50 & 50 & 50 \\
\hline Soybean meal & 22 & 22 & 22 & 22 \\
\hline Yellow corn & 6 & 6 & 6 & 6 \\
\hline Wheat bran & 8 & 8 & 8 & 8 \\
\hline Wheat flour & 5.925 & 3.925 & 3.925 & 3.925 \\
\hline Premix ${ }^{1}$ & 2 & 2 & 2 & 2 \\
\hline Sun flower oil & 3 & 3 & 3 & 3 \\
\hline Di calcium phosphate & 0.05 & 0.05 & 0.05 & 0.05 \\
\hline Mono calcium phosphate & 0.025 & 0.025 & 0.025 & 0.025 \\
\hline Fenugreek $(\mathrm{F})^{2}$ & - & 2 & 2 & 2 \\
\hline Thyroxin $(\mathrm{T} 4)^{3}$ & - & - & $0.5 \mathrm{mg}$ & - \\
\hline potassium iodide $(\mathrm{I})^{4}$ & - & - & - & $0.1 \mathrm{~g}$ \\
\hline Crud protein $(\mathrm{CP})$ & 44.6 & 45.1 & 45.1 & 45.1 \\
\hline Ether extract & 11.3 & 11.6 & 11.6 & 11.6 \\
\hline
\end{tabular}




\begin{tabular}{|c|c|c|c|c|}
\hline \multirow{2}{*}{ Ingredients composition } & \multicolumn{4}{|c|}{ Composition (\%) experimental diets. } \\
\hline & Control & Fenugreek (F) & Fenugreek + T4 (FT4) & Fenugreek + I (Fi) \\
\hline Crude fiber & 2.87 & 2.88 & 2.88 & 2.88 \\
\hline Nitrogen free extract (NFE) & 28.96 & 28.69 & 28.69 & 28.69 \\
\hline Ash & 12.3 & 11.7 & 11.7 & 11.7 \\
\hline Metabolizable energy $(\mathrm{kcal} / 100 \mathrm{~g})^{5}$ & 380.3 & 384.3 & 384.3 & 384.3 \\
\hline Digestible energy $(\mathrm{kcal} / 100 \mathrm{~g})^{6}$ & 426.1 & 430.3 & 430.3 & 430.3 \\
\hline Gross energy $(\mathrm{kcal} / 100 \mathrm{~g} \mathrm{DM})^{7}$ & 477.2 & 482.1 & 482.1 & 482.1 \\
\hline P: E ratio (mg CP: kcal) & 93.4 & 93.6 & 93.6 & 93.6 \\
\hline
\end{tabular}

${ }^{1}$ Premix Composition: - Each $1 \mathrm{~kg}$ contains Vit A (400000 i.u.), Vit D3 (100000 i.u.), Vit E (230 mg) Vit K3 (165mg) Vit B1 (300 mg), Vit B2 ( $80 \mathrm{mg}$ ), Vit B6 (200mg), Vit B12 (1mg), Vit C (650mg), Niacin (1000mg), Methionine(3000mg), Choline chloride (10000mg), Folic acid (100mg), Biotin (2mg), Pantothenic acid (220mg), Magnesium sulphate (1000mg), Copper sulphate (1000mg), Iron sulphate ( $330 \mathrm{mg})$, Zinc sulphate (600mg), Cobalt sulphate (100mg), Calcium carbonate up to $(1000 \mathrm{~g})$.

${ }^{2}$ (F) Fenugreek ${ }^{3}$ (T4) Eltroxin ${ }^{\circledR}$ tablets $100 \mu g$ GlaxoSmithKline co. ${ }^{4}$ (I) Potassium Iodide El Nasr pharmaceutical chemicals co.

${ }^{5}$ Metabolizable energy (M E) was calculated as $4.5,8.1$ and $3.49 \mathrm{kcal} / 100 \mathrm{~g}$ for protein, lipid and NFE, respectively according to pantha, (1982). ${ }^{6}$ Digestible energy (DE) was calculated as $5 ; 9$; and $3.5 \mathrm{kcal} / 100 \mathrm{~g}$ for protein, lipid, and carbohydrates respectively.

${ }^{7}$ Gross energy (GE) was calculated as 5.64, 9.44 and $4.11 \mathrm{kcal} / 100 \mathrm{~g}$ for protein, lipid and NFE, respectively NRC, (1993).

\subsection{Body Indices}

After blood samples collection, all fish samples were scarified and soon the abdominal cavity of 3 fish from each aquarium was opened to remove viscera to be weighed at once. Viscera and liver were weighed and (HSI and VSI) indices were calculated. Digestive tract $(\mathrm{cm})$, liver and viscera weights $(\mathrm{g})$ were randomly recorded for three fish from each aquarium to calculate certain biometric parameters such as viscerosomatic and hepatosomatic indices.

\subsection{Chemical Analysis of Diets and Fish}

The test diets and whole-fish body from each treatment were analyzed according to the standard methods of [7] for moisture, crude protein, crude fat and ash. Moisture content was estimated by drying the samples to constant weight at $105^{\circ} \mathrm{C}$ in a drying oven thermostatically regulated overnight. Protein content (on dry weight basis) was estimated as the total nitrogen content using the semi-automatic kjeldahl (Model VELP Scientifica, UDK 127). Crude protein was estimated by multiplying nitrogen content by 6.25 . Lipid content was determined in multi-unit extraction Soxhlet apparatus with petroleum ether as the extraction solvent. Ash was determined by combusting dry samples in a muffle furnace at $600{ }^{\circ} \mathrm{C}$. Crude fiber sample of one gram from each of experimental diets was treated with sulfuric acid then with sodium hydroxide at $1.25 \%(\mathrm{w} / \mathrm{w})$ for half an hour each, keeping the volume constant with boiling water. The final residues were washed with $5 \%$ hydrochloric acid (HCL) to get rid of adhering sodium hydroxide, washed with water then filtered, dried and weighed.

\subsection{Some Biometric Indices}

At the end of this period some fish were scarified to obtain their final biological records, such as total length, total weight, gut length, liver and viscera weights in order to determine hepatosomatic (HSI), viscerosomatic (VSI) indices, condition factor (CF), Relative gut length (RGL) and Relative intestine length (RIL). HSI was determined according to [8] as follows: HSI $=100$ [liver weight (g)/ total body weight (g)]; Viscerosomatic index (VSI): Was estimated according to Ricker (1979) as follows: VSI $=100$ [viscera weight $(\mathrm{g}) /$ total body weight $(\mathrm{g})] ;(\mathrm{CF})=100 *\left(\mathrm{TW} / \mathrm{T}^{3}\right)$ Where: $\mathrm{TW}=$ Total weight $(\mathrm{g}) ; \mathrm{L}=$ Total fish length $(\mathrm{cm})$. Relative gut length (RGL): was determined according to [9] as follows: $(\mathrm{RGL})=$ absolute gut length $(\mathrm{cm}) / \mathrm{L}(\mathrm{cm})$.

\subsection{Fish Performance}

Growth rate and feed utilization efficiency indices were calculated as mentioned by [10] as follows: Weight gain=final weight $(\mathrm{g})$-initial weight $(\mathrm{g})$; Specific growth rate $(\mathrm{SGR})=100(\ln . \mathrm{W} 2-\ln \mathrm{W} 1) / \mathrm{T}$; where $\mathrm{W} 1$ and $\mathrm{W} 2$ are the initial and final weight respectively, and $\mathrm{T}$ is the number of days of feeding period; Feed conversion ratio $(\mathrm{FCR})=$ feed intake (g) /weight gain (g); Protein efficiency ratio $(\mathrm{PER})=$ weight gain $(\mathrm{g}) /$ protein intake $(\mathrm{g})$; Protein productive value $(\mathrm{PPV})=100[$ protein gain $(\mathrm{g}) /$ protein fed $(\mathrm{g})]$ and Energy utilization $(\mathrm{EU} ; \%)=100 \times($ energy gain $(\mathrm{g}) / \mathrm{energy}$ intake (g)).

\subsection{Histological Examination}

Middle intestine sections for histological studies were fixed by immersion in $10 \%$ neutral $(\mathrm{pH}=7)$ buffer formalin solution. Intestine was dehydrated by ethyl alcohol graded levels. After that samples were embedded in paraffin wax by routine techniques. Sections of $5 \mu \mathrm{m}$ were obtained from the paraffin blocks and stained with Hematoxylin and Eosin (H\&E) and examined under binocular microscope at magnifications X400 and X1000 [11]. Intestine sections were submitted to measurement of thickness of muscularis, mucosal folds and number of villi, Goblet cells.

\subsection{Statistical Analyses}

Mean value and standard deviation (mean \pm SD) for each parameter of all treatments was first calculated. The results were subjected to one way analysis of variance (ANOVA) to test the effect of treatment inclusion on fish performance. Data were analyzed using SPSS program, Version 16[12]. Differences between means were compared using Duncan multiple range test at $\mathrm{P}<0.05$ level. 


\section{Results and Discussion}

\subsection{Growth Performance}

The average initial weight, final weight, specific growth rate and survival rate (\%) of sea bream fingerlings are presented in Table (2). The presented data in Table (2) show that the average final body weight at the end of the experiment for all groups were found to be 7.4, 7.4, 6.9 and $7.6 \mathrm{~g}$, respectively. The obtained result showed insignificant $(\mathrm{P}>0.05)$ difference between the control diet and all tested groups. No significant differences were recorded in survival rate $(\mathrm{P}>0.05)$ differences among all fish groups. Sea bream fed diet containing $2 \%$ Fenugreek seeds or fenugreek with (thyroxin or iodine) had insignificantly $(\mathrm{P}>0.05)$ growth parameters (FW, WG, PWG, DWG \% and SGR) comparing with those fed the control diet. These results disagreed generally with those reported by [13].who found that Nile tilapia fed diets containing $2 \%$ Fenugreek had significantly higher $(\mathrm{P}<0.05) \mathrm{FW}, \mathrm{W}$ G and SGR. Also, [14] reported that diet containing $1 \%$ fenugreek was the best supplemented level for FER\%, PER, APU and EU in comparison to the control and other treatment $(0,0.5,1$ and $1.5 \%$ test fenugreek levels).The lowest significantly due to the increase fenugreek in fish diet up to $1 \%$. Improve in $\mathrm{FW}, \mathrm{WG}, \mathrm{PWG}$, DWG \%, SGR and SR may be due to antibacterial related to flavonoids in Fenugreek [15]. The present study showed that sea bream fed fenugreek with iodine (Fi) had lower results in growth performance, feed utilization efficiency. These results may be explained by the ability of sea bream, as a marine fish, to absorb iodine for osmoregulation from the surrounding water via their gills and from the diet where it is easily absorbed in the digestive tract [16] and consequently the level of iodine in fish of Fi group become higher than normal. Many literatures revealed that, decreased growth, mental retardation, reduced egg hatchability, increased mortality and decreased fertility have been observed in terrestrial vertebrates fed insufficient [17], [18] or excessive iodine [19].. In contrast, [20] recorded an increase in Atlantic cod (Gadus morhua) larval iodine concentrations by 3 and 7 fold compared to control during the rotifer feeding period and they found no differences in growth were observed, They suggested that iodine toxicity in fish larvae may be determined to a greater extent by iodine bioavailability and nutrient interactions rather than by body burdens of iodine.

Table (2). Effects of dietary F; Fi and FT4 on growth performance and feed utilization of seabream (mean $\pm S E)$ for84 days.

\begin{tabular}{|c|c|c|c|c|}
\hline Item & control & fenugreek seed & fenugreek +iodide & fenugreek + thyroxin \\
\hline Initial body weight (IW,g/fish) & $1.88 \pm .01$ & $1.89 \pm .01$ & $1.89 \pm .01$ & $1.9 \pm .01$ \\
\hline Final body weight (FW,g/fish) & $7.41 \pm .05^{\mathrm{ab}}$ & $7.6 \pm .13^{\mathrm{ab}}$ & $6.9 \pm .07^{b}$ & $7.4 \pm .45^{\mathrm{ab}}$ \\
\hline Total weight gain (TWG,g/fish) & $5.53 \pm .051^{\mathrm{ab}}$ & $5.71 \pm .14^{\mathrm{ab}}$ & $5.05 \pm .06^{\mathrm{b}}$ & $5.5 \pm .46^{\mathrm{ab}}$ \\
\hline Specific growth rate(SGR,\%/d) & $2.04 \pm .01^{\mathrm{ab}}$ & $2.07 \pm .029^{\mathrm{ab}}$ & $1.93 \pm .015^{\mathrm{b}}$ & $2.02 \pm .099^{\mathrm{ab}}$ \\
\hline Feed intake(FI,g/fish) & $11.79 \pm .29^{\mathrm{ab}}$ & $11.17 \pm .23^{b}$ & $12.5 \pm .24^{\mathrm{a}}$ & $11.24 \pm .44^{\mathrm{b}}$ \\
\hline Protein intake (PI,g/fish) & $5.08 \pm .13^{\mathrm{b}}$ & $4.93 \pm .1^{\mathrm{b}}$ & $5.51 \pm .1^{\mathrm{a}}$ & $4.92 \pm .19^{b}$ \\
\hline Protein efficiency ratio(PER) & $1.09 \pm .03^{\mathrm{b}}$ & $1.16 \pm .03^{\mathrm{ab}}$ & $0.917 \pm .017^{\mathrm{c}}$ & $1.12 \pm .05^{\mathrm{ab}}$ \\
\hline Protein productive value (PPV \%) & $20.25 \pm .63^{\mathrm{b}}$ & $20.74 \pm .57^{\mathrm{b}}$ & $20.33 \pm .37^{\mathrm{b}}$ & $23.99 \pm .99^{\mathrm{a}}$ \\
\hline Energy utilization (EU, \%) & $11.16 \pm .33^{\mathrm{a}}$ & $7.94 \pm .20^{\mathrm{bc}}$ & $6.55 \pm .11^{\mathrm{c}}$ & $9.01 \pm .63^{b}$ \\
\hline Survival rate $(\mathrm{SR}, \%)$ & $96 \pm 2.08^{\mathrm{a}}$ & $97.9 \pm 2.08^{\mathrm{a}}$ & $93.7 \pm 3.6^{\mathrm{a}}$ & $96 \pm 2.08^{\mathrm{a}}$ \\
\hline
\end{tabular}

Means in the same rows having different letters are significantly $(\mathrm{P}<0.05)$ different.

\subsection{Feed Utilization Efficiency}

Table (2) illustrate the feed utilization indices for seabream at the end of feeding trials. Obtained results reveal that feed intake (FI) insignificant $(\mathrm{P}>0.05)$ different in all tested groups comparing with $\mathrm{C}$ group. Fish fed Fi diet shows highest FI rate as compared with fish fed other tested diets (12.5 g/fish).Best food conversion ratio (FCR) was obtained for fish fed $F$ diet (1.95), meanwhile, relatively the worst FCR (2.47) was that recorded for fish fed Fi diet which was significantly different the all other diets fish groups. Protein efficiency ratio (PER) values was varied in range ( 0.92 for fish fed Fi diet, 1.16 for fish fed $\mathrm{F}$ diet). These variations were tested to be significant $(\mathrm{P}<0.05)$ between FS and all other fish groups. Best Protein productive values (PPV) recorded in FT4 (23.09 and) and these value was significant $(\mathrm{P}<0.05)$ higher comparing with all other fish groups even $\mathrm{C}$ group. Energy utilization (EU, \%) values were varied within wide range from $6.55 \%$ in $\mathrm{Fi}$ group, which was significant $(\mathrm{P}<0.05)$ different comparing with all groups, to $(11.1 \%)$ in $\mathrm{C}$ group. [21] At Dicentrarchus labrax species after the administration of thyme, rosemary and fenugreek diets, in a concentration of $1 \% / \mathrm{kg}$ feed, the best values of growth indicators (SGR, FCR, PER) were met in case of thyme . [22] showed that thyme, added in a concentration of $1 \% / \mathrm{kg}$ feed, has a beneficial effect over the productivity of Oreochromis niloticus species reared in a recirculating aquaculture system, also fenugreek helped to increase growth performance, but less successful than thyme. [23] Study the effect of dietary inclusion of graded levels $(0,1$, and $2 \%)$ of Fenugreek seed meal (FSM) on Nile tilapia fry performance, for 16 weeks. From the obtained results, it was confirmed that, FSM had significantly (and proportional to the increase in its addition level) improved the feed utilization in form of PPV \% and ER. It improved significantly also (at $2 \%$ addition level) fish carcass protein percent, fenugreek and Cresson containing diets were superior to the control. The diet containing $2 \%$ fenugreek was the best in PPV \% while that containing $1 \%$ fenugreek was the best in EU \%. On the other hand, 
Seabream fed diet containing $2 \%$ soaked fenugreek seeds had significantly $(\mathrm{P}<0.05)$ growth parameters $(\mathrm{FW}, \mathrm{WG}$, PWG, DWG \% and SGR) and feed utilization these fed the other diet. However, Also, [13] reported that the survival rate of Nile tilapia fed diets containing different levels of fenugreek $(0,2,4,6$ and $8 \%)$ was within normal range .It recorded $100 \%$ for all fish groups except those fed diets containing 6 and $8 \%$ FSM levels which gave $95 \%$ survival rate for both. Based on the previous results reported by [24] the suitable doses of fenugreek seeds powder fed to weanling rates at dietary doses of 1,5 , and $10 \%$ in a pure diet had no toxicity. Feed intake was increased significantly $(\mathrm{P}<0.05)$ in diet containing 1 and $1.5 \%$ FSM. Diet containing $1 \%$ was the best supplemented level for FCR, FER and PER in comparison to the control and other diets FSM levels. The high values of APU and EU observed in diets containing 1\% FSM. These results in agreement with obtained of [13].FSM may have a negative impact on the environment and parasite resistance to poisonous chemicals can develop after repeated applications [25].

\subsection{Body Composition}

Table (3) illustrates fish body composition at the begging and end of feeding trial including dry matter (DM \%), crude protein (CP, \%), lipid (\%) and ash (\%). Moisture content in F and FS fish groups were almost similar (71.87 and $71.73 \%$ respectively) and significantly different comparing with control group and other tested fish. Protein content in Fi group was relatively close to (66.7). The same observation was also recognized by F and FT4 groups (63.3 and $63.8 \%$ respectively). Lowest Protein content was in fish fed $\mathrm{C}$ diet $(58.3 \%)$ and it was significantly different when compared with all tested group.

Table (3). Body composition of sea bream fed F, Fi; FT4and FS diets for84 days (mean \pm SE).

\begin{tabular}{|c|c|c|c|c|c|}
\hline \multirow[t]{2}{*}{ Item } & \multicolumn{5}{|c|}{ Experimental diets } \\
\hline & Initial fish & control & fenugreek seed & Fenugreek +iodide & fenugreek + thyroxin \\
\hline Moisture & $73.38 \pm 1.01$ & $68.8 \pm 0.52^{b}$ & $71.87 \pm .39^{\mathrm{a}}$ & $68.53 \pm .46^{b}$ & $67.69 \pm 0.46^{b}$ \\
\hline Crude protein & $67.47 \pm 1.59$ & $58.3 \pm .44^{c}$ & $63.3 \pm .54^{b}$ & $66.7 \pm .48^{\mathrm{a}}$ & $63.8 \pm .53^{\mathrm{b}}$ \\
\hline Lipid & $11.76 \pm 1.59$ & $26.02 \pm .26^{\mathrm{a}}$ & $18.49 \pm .28^{b}$ & $16.27 \pm .14^{\mathrm{d}}$ & $18.92 \pm .19^{b}$ \\
\hline Ash & $20.35 \pm 1.59$ & $15.34 \pm .06^{\mathrm{d}}$ & $17.58 \pm .07^{\mathrm{a}}$ & $16.31 \pm .07^{\mathrm{b}}$ & $16.53 \pm .07^{b}$ \\
\hline
\end{tabular}

Means in the same rows having different letters are significantly $(\mathrm{P}<0.05)$ different.

The highest lipid content was recorded in control $(26.02 \%)$ meanwhile; the lowest was recorded in fish fed Fi (16.27\%) diet. Lipid content was insignificantly different between $\mathrm{F}$ and FT4 groups (18.49 and $18.92 \%$ respectively). The highest ash content was recorded in $\mathrm{F}$ group (17.58\%) meanwhile lowest the ash content in was recorded for control group (15.34\%). Ash content values show significant variations between fish fed either control or any of the test fish groups (table 3). The percentages of dry matter (DM) and crude protein (CP) had increased by aging (after 112 days experimental period) but the ether extract and ash percentages had decreased [23]. On the other hand, Dry matter, crude protein, fat and ash in fish body did not be affected by different FSM levels. These results are in agreement with those obtained by [26], [13]. [27] Suggested that the functional, nutritional and therapeutic characteristics of fenugreek polysaccharide can be exploited further in the development of healthy extruded products. Due to the distinct bitter flavour of fenugreek flour it is difficult incorporate more than $2 \%$ level in extruded chickpea based products.

\subsection{Biometric Aeasurements}

At the end of feeding trial, viscerosomatic (VSI) and hepatosomatic (HSI) indices as well as condition factor (CF), relative gut length (RGL) and relative intestine length (RIL) of experimental fish groups were calculated, summarized in Table (4). As a general observation values of HSI and VSI for all tested fish groups were insignificantly varied among each other $(\mathrm{P}>0.05)$. VSI values were ranged between 4.63 for fish fed FS diet and 5.96 for fish fed F diet. On the other hand, the highest condition factor $(\mathrm{CF})$ value was obtained in $\mathrm{C}$ fish group (1.51) and this value was significantly lower in all treatments except in $\mathrm{F}$ group (1.41) $(\mathrm{P}<0.05)$.

Table (4). Biometric measurements (mean \pm SE) of seabream fed F, Fi and FT4 diets for84 days.

\begin{tabular}{llll}
\hline Item & \multicolumn{3}{c}{ Experimental diets } \\
\hline & C & F & Fi \\
\hline viscerosomatic indices & $4.68 \pm 0.7$ & $5.96 \pm 0.6$ & $5.5 \pm 0.5$ \\
hepatosomatic indices & $1.36 \pm 0.16$ & $1.35 \pm 0.29$ & $1.53 \pm 0.15$ \\
condition factor & $1.51 \pm 0.04^{\mathrm{a}}$ & $1.41 \pm 0.03^{\mathrm{ab}}$ & $1.32 \pm 0.06^{\mathrm{b}}$ \\
relative gut length & $1.07 \pm 0.08^{\mathrm{b}}$ & $1.41 \pm 0.09^{\mathrm{a}}$ & $1.08 \pm 0.09^{\mathrm{b}}$ \\
relative intestine length & $0.89 \pm 0.07^{\mathrm{b}}$ & $1.22 \pm 0.08^{\mathrm{a}}$ & $0.89 \pm 0.08^{\mathrm{b}}$ \\
\hline
\end{tabular}

Means in the same rows having different letters are significantly $(\mathrm{P}<0.05)$ different.

Highest (RGL) was recorded in fish fed F diet (1.41) and this value was higher significantly when compared with 
either C (1.07) or Fi and FT4 groups (1.08 and 1.07 respectively) highest (RGL) value was for F group (1.41) and it was significantly different with all other groups. Relative intestine length (RIL) values also show the same trend of variations comparing with RGL values.

\subsection{Serum Constituents}

Table (5) illustrate that serum total protein concentration of group Fi significantly higher $(\mathrm{P}<0.05)$ comparing with $\mathrm{C}$ and other treated fish groups. Serum total lipid was significantly different $(\mathrm{P}<0.05)$ among of all fish groups treatments .The serum cholesterol concentration has significant $(\mathrm{P}<0.05)$ difference between $\mathrm{Fi}$ and other treated groups. Concentration of thyroid hormone (T4) was the lowest in fish fed with dietary Fi. The fish group fed Fi had significantly $(\mathrm{P}<0.05)$ lowers concentration. Lipase activity was significantly $(\mathrm{P}<0.05)$ different among different $\mathrm{F}$ tested diets. Amylase content in blood serum was varied in range of 0.3 to 2.0u/l in F and Fi fish groups respectively.

Table (5). Serum constituents (mean \pm SE) of seabream fed F, Fi and FT4 diets for 84 days.

\begin{tabular}{lllll}
\hline Item & Experimental diets & & & \\
\hline & C & F & Fi & FT4 \\
\hline Total protein g/dl & $2.5 \pm 0.06^{\mathrm{b}}$ & $2.29 \pm 0.13^{\mathrm{b}}$ & $3.02 \pm 0.12^{\mathrm{a}}$ & $2.38 \pm 0.04^{\mathrm{b}}$ \\
Total Lipid g/dl & $1.12 \pm 0.06^{\mathrm{c}}$ & $0.96 \pm 0.15^{\mathrm{f}}$ & $1.03 \pm 0.10^{\mathrm{d}}$ & $1.23 \pm 0.11^{\mathrm{b}}$ \\
Cholesterol mg/dl & $0.11 \pm 0.5^{\mathrm{c}}$ & $0.11 \pm 0.4^{\mathrm{c}}$ & $0.20 \pm 0.7^{\mathrm{a}}$ & $0.13 \pm 0.1^{\mathrm{bc}}$ \\
$(\mathrm{T} 4) \mu \mathrm{g} / \mathrm{dl}$ & $4.1 \pm 0.16^{\mathrm{ab}}$ & $4.26 \pm 0.06^{\mathrm{ab}}$ & $4.05 \pm 0.08^{\mathrm{b}}$ & $4.48 \pm 0.01^{\mathrm{a}}$ \\
Lipase u/l & $7.5 \pm 0.5^{\mathrm{d}}$ & $18.7 \pm 0.14^{\mathrm{a}}$ & $7.5 \pm 0.7^{\mathrm{d}}$ & $11.2 \pm 0.15^{\mathrm{c}}$ \\
Amylase $\mathrm{u} / 1$ & $1.0 \pm 0.1^{\mathrm{b}}$ & $0.3 \pm 0.1^{\mathrm{c}}$ & $2 \pm 0.2^{\mathrm{a}}$ & $0.4 \pm 0.1^{\mathrm{c}}$ \\
\hline
\end{tabular}

Means in the same rows having different letters are significantly $(\mathrm{P}<0.05)$ different.

In this study, we assessed some of haematological and biochemical parameters and their effect in the normal health status of Nile tilapia during experiment period. The blood and biochemical parameters were affected by fenugreek seeds meal as natural feed additives, in diets for fingerlings monsex Nile tilapia. [23] Study set out to determine which percentage fed fenugreek is suitable for fish health. Blood and biochemical studies were done to understand the changes in the protein, lipid levels after feeding.

Haematological indices are an index and a reflection of the effects of dietary treatments on the animal in terms of the type, quality and amounts of the feed ingested and were available for the animal to meet its physiological, biochemical and metabolic necessities [28], in this regard, all haemotological parameters analyzed $(\mathrm{Hb}, \mathrm{PCV}$ and $\mathrm{RBCs}$ ) for Nile tilapia were significantly increased. This could be attributed to the increase in the blood parameters to shift of water from the plasma to the muscle cells, thereby increasing the hemoconcentration [29]. The concentration of total protein in blood plasma is used as a basic index for the health status of brood fish [30] as measurement of serum or plasma albumin is of considerable diagnostic value in laboratory animals as it relates to general nutritional status, the integrity of the vascular system and liver function. [18] Reported that total protein level increased significantly $(\mathrm{p}<0.05)$ as a result increases protein in diet [31]. Fish fed on $1 \%$ and $1.5 \%$ fenugreek in diet exhibited the highest values of albumin and globulin respectively both increased significantly but $\mathrm{A} / \mathrm{G}$ ratio is non-significantly decreased, these might be because fenugreek is a rich source in selenium that aid increase production of albumin and globulin in liver [32] moreover albumin and globulin concentrations are commonly used for evaluating the effect of nutrients on the fish immunity. Low albumin may result from impaired synthesis, loss though urine or feces or increased catabolism [33]. The increase in the serum protein and globulin levels is thought to be associated with a stronger innate response in fish [34] and the decrease in the $\mathrm{A} / \mathrm{G}$ ratio is indicative of better immunity of the animal, which may occur due to an increase in the globulin level compared with albumin. The increase in total serum protein and globulin indicates that fish are immunologically strong [35].

Plant protein appears to lower cholesterol level [36], in the present work total lipid is significantly decreased by increase fenugreek in fish diet, because fenugreek seed would be considered as effective agent for lipid lowering purposes [37] and it is in rich protein $(26 \%)$ has added advantage in that it is a good source of protein as well as fibre (48\%) and it might exert a lipid lowering effect [38] moreover, the ability of fenugreek alkaloids treatment to reduce blood serum lipids including total lipids [39].

Studies in rodents indicate that fenugreek has immune stimulating, antioxidant and anti-tumor properties, and protects the liver against alcohol toxicity. Also, fenugreek seeds exhibited appreciable antioxidant property in vitro which was comparable with that of reduced glutathione and vitamin E. Further, examination of liver and brain revealed that, extract of fenugreek seeds could offer a significant of fenugreek seeds could offer a significant protection against ethanol toxicity. Fenugreek also has antiulcer properties [40]. It is concluded that the using FKSM as natural feed additives in fish diet, especially at $1 \%$ can improve the growth performance, feed utilization and immune response. These positive effects of the used feed additives are due to their active pharmacological (medical) substances. Since the therapeutic role of Trigonella seed powder in type1 diabetes can be attributed to the change of glucose and lipid metabolizing enzyme activities to normal values, thus stabilizing glucose homeostasis in the liver and kidney [41]. Trigonella foenum-graecum L. has also an 
immunomodulatory activity, so it is widely used as a medicinal and dietary herb. The antineoplastic effect of Trigonella foenum-graecum seed extract has been evaluated. The extract also produced a significant anti-inflammatory effect [42].

\subsection{Histological Characteristics of Intestine the Seabream}

The morphological structure of the intestine was examined using light microscopy. Some representative sections are shown in Figure (1).The intestine is made up of four distinct layers: outer Serosa, muscularis, sub mucosa and mucosal epithelium. Inner circular and outer longitudinal muscle layers were evident and mucosa was thick and interspersed with absorptive epithelial cells and numerous mucus-secreting Goblet cells. At the end of experiment, the thickness of muscularis layer, the height of mucosal villi and the number of its Goblet cells were measured in the middle part of intestine for each of the control and treated groups. The results are shown in table (6) and Figure (1).

Table (6). Average of height of mucosa, Thickness of muscularis and number of goblet cells in the intestine of seabream fed F, Fi and FT4 diets for 84 days.

\begin{tabular}{lllll}
\hline Item & Experimental diets & & & \\
\hline & C & F & Fi & FT4 \\
\hline No. Villi in section & $18 \pm 0.36^{\mathrm{c}}$ & $19 \pm 0.26^{\mathrm{b}}$ & $16 \pm 0.26^{\mathrm{e}}$ & $21 \pm 0.31^{\mathrm{a}}$ \\
Thickness of muscularis $(\mu)$ & $20 \pm 0.36^{\mathrm{a}}$ & $13 \pm 0.73^{\mathrm{c}}$ & $15 \pm 0.36^{\mathrm{b}}$ & $13 \pm 0.26^{\mathrm{c}}$ \\
Goblet cells & $6.8 \pm 0.48^{\mathrm{b}}$ & $17.8 \pm 0.48^{\mathrm{a}}$ & $3.3 \pm 0.21^{\mathrm{c}}$ & $8 \pm 0.36^{\mathrm{b}}$ \\
Villi length $(\mu)$ & $107 \pm 6.1^{\mathrm{c}}$ & $82.3 \pm 1.9^{\mathrm{d}}$ & $170 \pm 5.9^{\mathrm{a}}$ & $132 \pm 3.0^{\mathrm{b}}$ \\
Villi width $(\mu)$ & $28 \pm 0.88^{\mathrm{b}}$ & $35.5 \pm 1.3^{\mathrm{a}}$ & $19.8 \pm 0.6^{\mathrm{c}}$ & $20 \pm 0.63^{\mathrm{c}}$ \\
\hline
\end{tabular}

Means in the same rows having different letters are significantly $(\mathrm{P}<0.05)$ different.
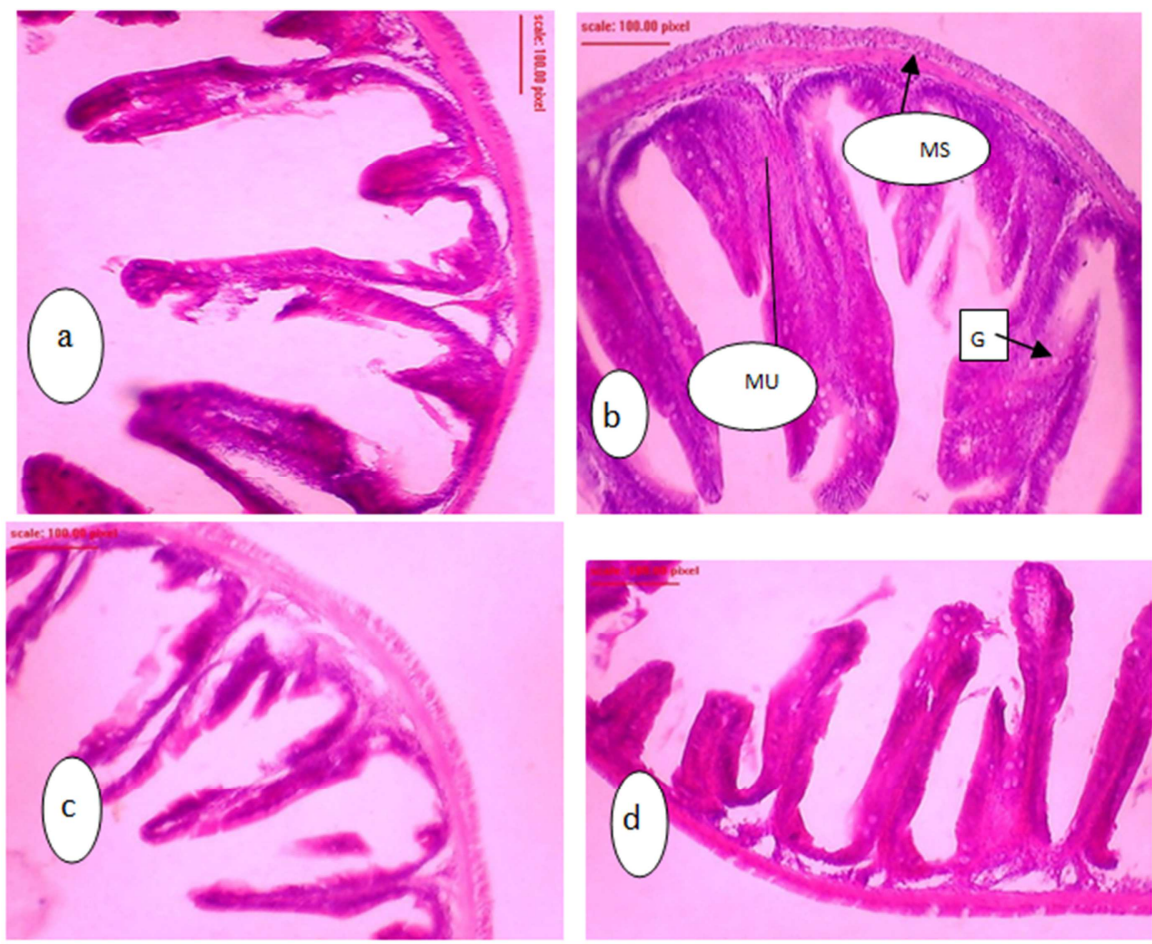

Figure (13). Photomicrograph of cross sections of intestine of the seabream. Showing mucosa (MU), Goblet cells (G); muscularis (MS) and Serosa. Hematoxylin and eosin stain ( $H \& E X 100)$ fish were fed a) $C$ b) F, c) Fi and d) FT4 diets for 84 days.

The present results showed remarkable variations between all the treatments and the $\mathrm{C}$ group. The heights of mucosal villi in all the treatments were greater than that in the Fi group for the middle intestine. The highest value for the mucosa was recorded in the intestine of fish treated with $\mathrm{F}$. Statistical analysis exhibited significant $(p<0.05)$ increases in the height of mucosa along the middle intestine for all the treatments compared to the Fi group. The thickness of muscularis of the whole intestine of seabream fed on different diets was higher than that for the Fi group.

In the same way the number of Goblet cells in the intestine of the seabream was higher in fish exposed to F compared to the control and Fi groups. The highest number of Goblet cells was observed in fish exposed to F.

In general, histological analysis showed satisfactory values in all the treatments compared to the Fi. F treatment was the most important treatment since it illustrated highest values of the height of mucosa, thickness of muscularis layer, and number of Goblet cells throughout the middle intestine compared to the FT4 and Fi groups.

Histological analysis detected that all the treatments showed satisfactory values compared to the control group 
with emphasize that FT4 and F was the most important treatment where it illustrated highest values of the height of mucosal folds, thickness of muscularis layer, and number of Goblet cells throughout middle parts of intestine compared to the control group. [43] Reported that the number of Goblet cells could vary with the food habit or starvation. According to [44], the intestine appeared to be the most active in the absorption of macronutrients suggesting that the observed effects may be play an important role in the adaptation of the reduced food intake.

\section{Conclusion}

According to the present results, Seabream fed diet containing $2 \%$ Fenugreek seeds is the most viable option for optimizing utilization and improving morphological structure of the intestine in culture even when compared with control diet. The present study is a preliminary study and further research is needed to determine the most appropriate supplement levels for optimum growth results in larger fishes at a commercial scale.

\section{References}

[1] R.M. Rasha, G.A. El-Nobi, M.E. Hassanin, and A.G.Elmowalid, (2010): Effects of Some Feed Additives on Health and Growth of Nile tilapia Oreochromis niloticus Zag. Vet. J. (ISSN. 1110-1458) Vol. 38, No. 2 pp. 18-26.

[2] L. Boulos, (1983): Medicinal plants of North Africa. Library of congers, USA pp 325.

[3] K. Gupta, K.K. Thakral, S.K. Arora, and M.L. chowdhary, (1996): Structural carbohydrate and mineral contents of fenugreek seeds Indian Coca Arecenut and Species J., 20: 120.

[4] M.K. Osman, and L.S. Simon, (1991): Biochemical studies of some non-conventional sources of protein part 5 extractions and characterization of protein from fenugreek seed trigonella foenum graecum 1. Nahrung. 35(3): 303-308.

[5] D.A. Higgs, U.H.M. Fagerlund, J. G. Eales and J. R. McBride, (1982). Application of thyroid and steriod hormones as anabolic agents in fish culture. Comparative Biochemistry and Physiology 73B: 143-176.

[6] A.P. H. A. American Public Health Association, (1995). Standard methods for examination of water and waste water. 18th edition, Washington D.C., USA, 769.

[7] A.O.A.C. Association of Official Analytical Chemists, (1995). International Official methods of Analysis. $16^{\text {th }}$ edition, Arlington, Virginia, USA.

[8] C.B. Schreck, and P.B. Moyle, (1990): Methods for Fish Biology. Oregon Fishery Research Unit. U.S. Fish and Wildlife Service, Oregon State University. American Fisheries Society, Maryland, U.S.A. (Special report).

[9] A.H. Al-Hussini, (1947): The feeding habits and the morphology of the alimentary tract of some teleosts living in the neighbour hood of the Marine Biological Station, Ghardaqa, Red Sea. Pub Mar. Biol. St. Ghard. Red Sea, Vol. (5).
[10] R. Ballestrazzi, Lanari, D. Agaro, E.D. and A. Mono, (1994). The effect of dietary protein levels and source on growth, body composition, total amino acid and reactive phosphate excretion of growing seabass. Aquaculture, 127:197-206.

[11] R. Martoja, and M. Martoja-Pierson, (1970): Tecnicas de Histologia Animal. Toray-Masson, S A., Ed. Barcelona, 350 pp.

[12] SPSS, (1997). Statistical package for the social sciences, Versions16, SPSS in Ch, Chi-USA.

[13] S.M.M. Shalaby, (2004): Response of Nile tilapia, Oreochromis niloticus, fingerlings to diets supplemented with different levels of fenugreek seeds (Hulba). J. Agric. Mansoura Univ., 29, 2231-2242.

[14] A.A. Mostafa, Z.M. Ahmad, M.H. Mousa, M.H. and A.Samir, (2009): Effect of using dried fenugreek seeds as natural feed additives on growth performance, feed utilization, whole-body composition and entropathogenic Aeromonas hydrophila-challenge of monsex Nile Tilapia O. niloticus fingerlings. Aust. J. Basic Appl. Sci. 3(2): 1234-1245.

[15] M.A. Bhatti, M.T.J. Khan, B. Ahmed, M.J. Amshaid and W. Ahmed, (1996): Antibacterial activity of trigonella foenum Graceum seeds.Fitoterapia, 67(4): 372-374.

[16] L.A. Gregory, and J. G. Eales, (1975). Factors contributing to high levels of plasma iodide in brook trou Saluelinus fontinalis (Mitchill). Can. J. Zool., 53: 267-277.

[17] S.M. Robertson, M. A. Friend and B. J. King, (2008). Mild congenital goiter increases lamb mortality in southern New South Wales. Australian Journal of Experimental Agriculture, 48(6-7): 995-998.

[18] J. Dong, W.Y. Liu, Y. Wang, Y. Hou, H.D. Xu, J.A. Gong, Q. $\mathrm{Xi}$, and J. Chen, (2011). Developmental iodine deficiency and hypothyroidism impair spatial memory in adolescent rat hippocampus: involvement of camkii, calmodulin and calcineurin. Neurotoxicity Research 19(1): 81-93.

[19] D.H. Baker, T. M. Parr and N. R. Augspurger, (2003). Oral iodine toxicity in chicks can be reversed by supplemental bromine. Journal of Nutrition, 133(7): 2309-2312.

[20] T. Penglase, Ø. S. Harboe, S. Helland, A. Nordgreen and K. Hamre, (2013). Iodine nutrition and toxicity in Atlantic cod (Gadus morhua) larvae. Peer J., vol (1) doi: 10.7717/peerj.20.

[21] S. Yılmaz, S. Ergün, and E.Ş. Çelik, (2012): Effects of herbal supplements on growth performance of sea bass Dicentrarchus labrax Change in body composition and some blood parameters, J. BioSci. Biotech. 1(3), p. 217-222.

[22] A.V.C. Antache, D. Lorena, G. Iulia, D. Angela, I. Vasilean1, M. Mirela, and S.M. Petrea, (2013): the influence of some phytobiotics on growth performance indicators at Oreochromis niloticus, reared in an intensive recirculating aquaculture system. Lucrări Ştiinţifice-Seria Zootehnie, vol. 60,204-208.

[23] A.M. Abdelhamid, and A.A.A. Soliman, (2012a): Possibility of using fenugreek seeds or Cresson seeds in tilapia diets. Journal of the Arabian Aquaculture Society, 7 (1): 75- 90.

[24] N.K. Muradlidhara, S. Viswanatha, and B.S. Ramesh, (1999): Acute and sub-chronic toxicity assessmentll of debitterized fenugreek powder in the mouse and rat. Food chem..Toxicol., 37: 831-838. 
[25] E. Magi, and M. Sahk, (2003): Use of herbal medicine principle in local conditions. Agraarteadus, 14: 172-178.

[26] A. Abd Elmonem, S.M.M. Shalaby, and A.Y. El-Dakar, (2002): Response of red tilapia to different levels of some medicinal Plants by products black seed and roquette seed meal. Proceeding the $1 \mathrm{st}$ Scientific Conference on Aquaculture.13-15 December, El-Arish, Egypt, 247-280.

[27] S. Gamlath, and G. Ravindran, (2009): Extruded products with Fenugreek Trigonella foenumgraecium chickpea and rice: Physical properties, sensory acceptability and glycaemic index. Journal of Food Engineering, 90(1): 44-52.

[28] E.O. Ewuola, O.A. Folayan, F.A.Gbore, A.I. Adebunmi, R.A. Akanji, J.T. Ogunlade, and J.A. Adeneye, (2004): Physiological response of growing West African Dwarf goats fed groundnut shell-based diets as the concentrate supplements. BOWEN J. Agric., 1(1): 61-69.

[29] R. Wilson, and E. Taylor, (1993): The physiological responses of freshwater rainbow trout Oncorhynchus mykiss during acutely lethal copper exposure. Journal of Comparative physiology, 163B: 38 .

[30] J. Rehulka, (1996): Blood parameters in common carp with spontaneous spring Viremia (SVC). Aquaculture International, 4: $175-82$.

[31] R.Y. Vasudeva, M. Romesh, A. Singh, and R. Chakrabarti, (2004): Potentiation of antibody production in Indian major carp Labeo rohita, rohu, by Achyranthes aspera as aherbal feed ingredient. Aquaculture, 238: 67-73.

[32] A.M.H. EL- Marakby, H.I. Seden, M.E.A. Abdel-Tawwab, and M. Abou-El-Atta, (2006): The use of organic selenium (Sel-PlexO) in practical diets for Nile tilapia, Oreochromis niloticus: effect on growth performance, feed utilization, whole-body composition and entropathogenic Aeromonas hydrophila challenge. In: Contreras, W., Fitzsimmons, K. (Eds), 7th International Symposium on Tilapia in Aquaculture, 6-8 September. Boca Del Rio, Veracruz, Mexico, pp: 95-107.

[33] H.T. Nguyen, (1999): Transport proteins, In: Loeb, W.F., Q uimby, F.W. ( Eds), The clinical chemistry of Laboratory Animals, Second Edition. Taylor and Francis, Philadelphia, PA, USA. pp: 309-335.

[34] G.F. Wiegertjes, R.J.M. Stet, H.K. Parmentier, and W.B.VanMuiswinkel, (1996): Immunogenetics of disease resistance in fishes; a comparable approach Developmental and Comparative Immunology, 20: 365-381.
[35] A.K. Nayak, B.K. Das, M.P.S. Kohli, and S.C. Mukherjee, (2004): The immunosuppresive effect of ápermethrin on Indian major carp, rohu (Labeo rohita). Fish and Shellfish Immunology, 16(1): 41- 50.

[36] H. James, (2004): Atrovastatin reduces remnant lipoproteins and small, dense low-density lipoproteins regardless of the baseline lipid pattern. Prev Cardiol., 7: 154-60.

[37] M. Abu Saleh, U. Moosa, R. Mamun, A.Z.S. Asadi, A. Nazma, M. Mojib Uddin, and A. Ferdaus, (2006): Hypolipidemic effects of fenugreek seed powder. Bangladesh J Pharmacol. , 1: 64-67.

[38] R.D. Sharma, (1986): Effects of fenugreek seeds and leaves on blood glucose and serum insulin responses in human subjects. Nutr Res., 6: 1353-64.

[39] Y. Sauvaire, G. Ribes, J.K. Baccou, and M. Loubatieres-Mariani, (1991): Implication of steroid saponions and sapogenins in the hypocholesterolemic effect of fenugreek, lipids. 26: 191-197.

[40] M.D. Sahalian, (2004): Diosgenin, asteroid saponins of Trigonella foenum graecum (fenugreek), inhibits azoxymethane- induced aberrant crypt foic formation in F344 rats and induces apoptosis in HT-29 human colon cancer cells. Cancer Epidermiol biomarkers Prev. Aug., 13(8): 1392-8.

[41] J. Raju, J.M. Patlolla, M.V. Swamy, and C.V. Rao, (2004): "Diosgenin, a steroid saponin of Trigonella foenum graecum (Fenugreek), inhibits azoxymethane-induced aberrant crypt foci formation in F344 rats and induces apoptosis in HT-29 human colon cancer cells". Cancer Epidemiol Biomarkers Prev; 13: 1392-1398.

[42] P. Sur, M. Das, and A.Gomes, (2001): Trigonella foenum-graecum (fenugreek) seed extract as an antineoplastic agent. Phytother Res; 15:257-9.

[43] S.S. De Silva, and T.A. Anderson, (1995): Fish nutrition in Aquaculture, Chapman and Hall, London. Duncan db, 1955: Multiple range and multiple F-tests: Biometrics aiep. Vol, 2000: 1-2.

[44] E. Evangeline, E. Jaravata1, A. Herrera1, and S.A. Jose, (2004): Impact of The Quality of First Food on Digestive Enzymes and Development of The Anterior Intestine and Hepato pancreas of Genetically Male Nile Tilapia (Gmt) Oreochromis Niloticus, Freshwater Aquaculture Center, College of Fisheries, Central Luzon State University, Science City of Muñoz, Nueva Ecija 3120, Philippines, 316: 336. 